\title{
Timing of Shell Size Increase and Decrease of the Planktic Foraminifer Neogloboquadrina pachyderma (Sinistral) During the Pleistocene, IODP Exp. 303 Site U1304, the North Atlantic Ocean
}

\author{
M. Yamasaki ${ }^{*}, 1$, M. Matsui ${ }^{1}$, C. Shimada ${ }^{2}$, S. Chiyonobu ${ }^{3}$ and T. Sato ${ }^{1}$ \\ ${ }^{I}$ Institute of Applied Earth Sciences, Faculty of Engineering and Resource Science, Akita University, Akita 010-8502, \\ Japan \\ ${ }^{2}$ Mineral Industry Museum, Akita University, Akita 010-8502, Japan \\ ${ }^{3}$ Institute of Geology and Paleontology, Graduate School of Science, Tohoku University, Sendai 980-8578, Japan
}

\begin{abstract}
We made shell size measurements of the planktic foraminifer Neogloboquadrina pachyderma (sinistral) using samples from IODP Site U1304, the North Atlantic. We found that mean and maximum shell sizes began to increase around 1.1 Ma, and that several episodic changes in test size occurred during $0.6-0.35 \mathrm{Ma}$. Test size reached a maximum during the late Quaternary. Based on correlation with previous investigations, we have confirmed that these changes in foraminiferal shell size occurred on an inter-ocean scale.
\end{abstract}

Keywords: Planktic foraminifera, Shell size, IODP, North Atlantic, Quaternary.

\section{INTRODUCTION}

High latitude boreal seas are characterized by the extraordinary abundance of the planktic foraminifer Neogloboquadrina pachyderma (sinistral) (e.g. [1, 2]). Shell size of this species has recently been reported to have increased through the Quaternary in northern hemisphere oceans [3, 4]. Kucera and Kennett [4] found such trend in the North Pacific and claimed that "the modern type" of the species had appeared about $1 \mathrm{Ma}$. Generally, the shell size of foraminifera is believed to have increased during the Cenozoic, and maximized in the most favorable conditions [5]. In the case of N. pachyderma (sin), Huber et al. [3] suggested that such an increase in shell size would reflect their evolutional adaptation when cold waters progressively appeared in the high latitudinal seas together with increasing glaciation since the mid-Quaternary. However, most of these previous works have targeted upper Pleistocene and Holocene (1.3 Ma to the Recent) deposits off California and the Norwegian - Greenland Sea. In both regions N. pachyderma $(\sin )$ is not frequent but rather of sporadic occurrence during the early Pleistocene. In this paper, we describe the long-term trend in shell size change of $N$. pachyderma ( $\sin )$ from its main habitat, and to investigate the detailed timing of size increase using good quality core materials covering of the whole Quaternary period in the subarctic North Atlantic.

\section{MATERIALS AND METHODOLOGY}

Materials were obtained from IODP Site U1304 $\left(53^{\circ} 03^{\prime} \mathrm{N}, 33^{\circ} 31^{\prime} \mathrm{W}\right.$; water depth, $\left.3080 \mathrm{~m}\right)$, located within the North Atlantic subarctic convergence zone (Fig. 1). The

*Address correspondence to this author at the Institute of Applied Earth Sciences, Faculty of Engineering and Resource Science, Akita University, Akita 010-8502, Japan; Fax: +81-18-837-0401;

E-mail: yamasaki@ipc.akita-u.ac.jp sediments at the site consist of biogenic components, alternation calcareous nannofossil ooze and laminated diatomaceous ooze, with less common intervals of clay and silty clay which is rich in microfossils [6].

An age model for Site U1304 was established using paleomagnetostratigraphy and biostratigraphy of both calcareous nannofossil and diatom [6]. In total, 16 biostratigraphic datum levels spanning the last 1.8 million years were employed in this study.

For foraminiferal analyses including size measurements, 89 horizons were chosen down to 273.09 meters composite depth (mcd) from Holes U1304A and U1304B. Each $10 \mathrm{~cm}^{3}$ sample was first soaked in a $3 \%$ hydrogen peroxide solution for a few hours. Samples were then washed through a $63-\mu \mathrm{m}$ screen, and the retained particles were dried at $60^{\circ} \mathrm{C}$. The size fraction larger than $63 \mu \mathrm{m}$ was split into smaller aliquots with a microsplitter. Each sample was then dry sieved through a $125-\mu \mathrm{m}$ screen. Planktic foraminiferal shells larger than $125 \mu \mathrm{m}$ were picked from the aliquots until ideally 200 specimens were collected. All specimens were identified and counted. All specimens of $N$. pachyderma $(\sin )$ were oriented in the standard taxonomic umbilical view, and the maximum diameter of each specimen was measured and given as "shell size", using the public domain image analyzing software ImageJ (http://rsb.info.nih.gov/ij/index.html). In the case of samples with very low $N$. pachyderma $(\sin )$ abundances, another aliquot was used for obtaining additional specimens of $N$. pachyderma ( $\sin )$ for the size measurement. In our analysis, both of the two distinct ultrastructural morphotypes of $N$. pachyderma $(\sin )$ were measured, (1) the crystalline and (2) the reticulate morphotypes [7]. In total, 8849 specimens were measured. The mean, the 25 and 75 percentiles, outliers, and the range, which shows an interval between the 25 and 75 percentile, are given in Fig. (2). 


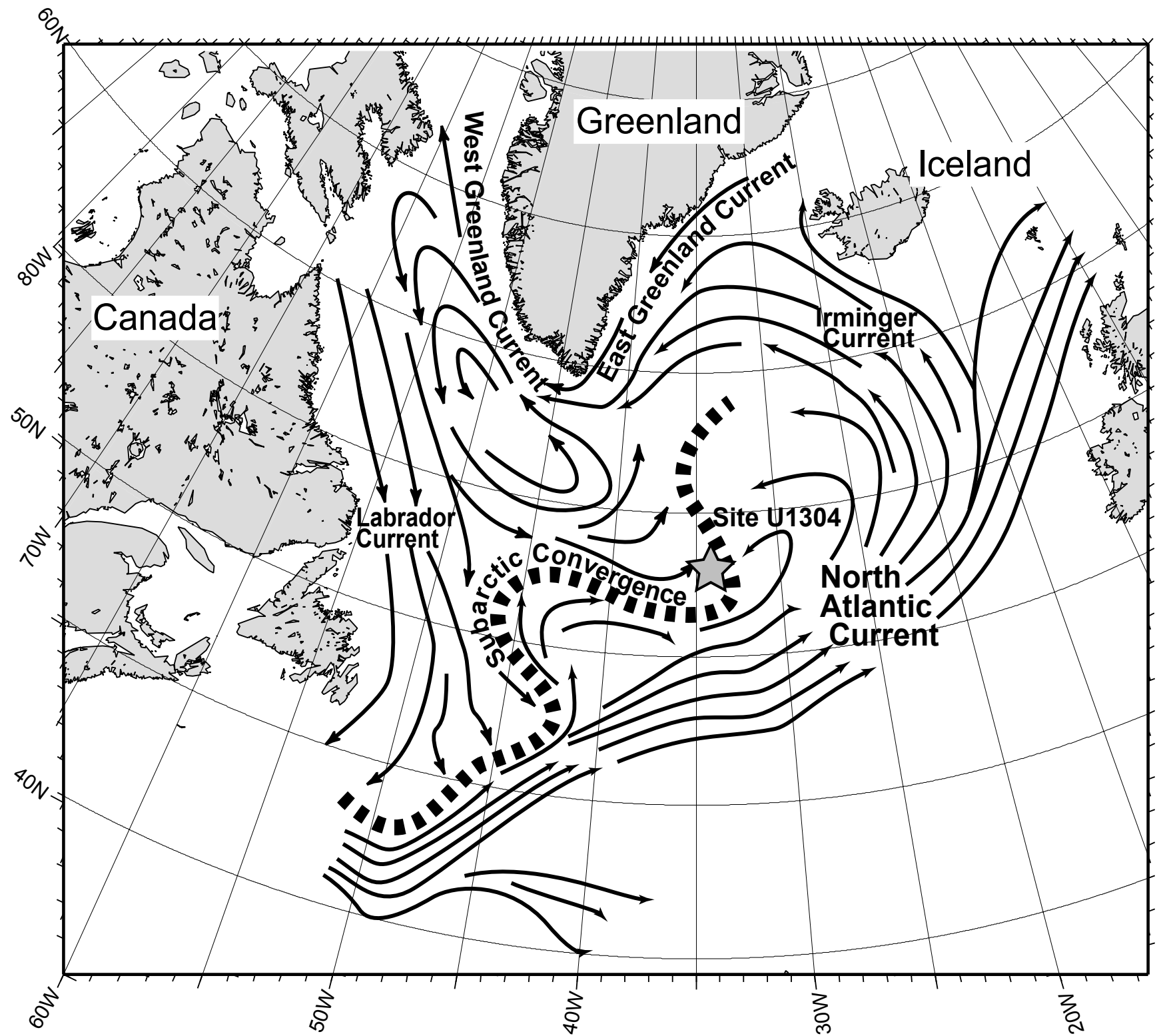

Fig. (1). Map showing the surface ocean currents, the North Atlantic subarctic convergence zone [21], and the study location.

\section{RESULTS}

Neogloboquadrina pachyderma ( $\sin$ ) was usually the most dominant species in the samples analysed (Table 1), accounting for up to $96.2 \%$ in relative abundance and $42.5 \%$ on average of the total planktic foraminiferal assemblages (Fig. 2). N. pachyderma ( $\sin$ ) increased in particular from the lowermost Pleistocene, confirming the work of Weaver and Clement [8] who presented a framework of the planktic foraminiferal biostratigraphy in the North Atlantic, and is also consistent with the report of Meggers and Baumann [9], who showed that $N$. pachyderma ( $\sin )$ abundantly occurred in the Labrador Sea since 1.1 Ma. The abundance of N. pachyderma ( $\sin )$ dropped to $<50 \%$ around 1.3 and $0.8 \mathrm{Ma}$, and from ca. 0.6 to $0.25 \mathrm{Ma}$.

The mean shell size (MSS) from a total of 8849 specimens was $220.6 \mu \mathrm{m}$. In addition, the MSS ranged from 187.0 to $237.7 \mu \mathrm{m}$ while sizes as large as $400 \mu \mathrm{m}$ were recorded in some horizons (Fig. 2 and Table 1). Both MSS and range in shell size were generally low $(190.9-227.5 \mu \mathrm{m})$ between 1.8 and 1.2 Ma. On the other hand, larger shells were often observed between $1.1-0.9 \mathrm{Ma}$, with a 75 percentile larger than $250 \mu \mathrm{m}$. At the same time, ranges became wider than that of the lower. Smaller values of MSS were recognizable again between $0.6-0.35 \mathrm{Ma}$, and the minimum MSS was $187.0 \mu \mathrm{m}$ at $0.36 \mathrm{Ma}$. In the following, there was a significant increase of MSS, and MSS eventually became larger than $250 \mu \mathrm{m}$ from $0.35 \mathrm{Ma}$ to the Recent. Though the correlation between MSS and percent abundance of N. pachyderma ( $\sin )$ is low $(r=0.19)$, smaller MSS were observed at low abundances of $N$. pachyderma $(\sin )$ within the total planktic foraminiferal assemblage during some periods (e.g., around $0.4 \mathrm{Ma}$ ).

\section{DISCUSSION}

Shell size changes of $N$. pachyderma $(\sin )$ during the late Quaternary were previously reported from the Norwegian Greenland Sea [3] and the North Pacific [4]. We can directly 


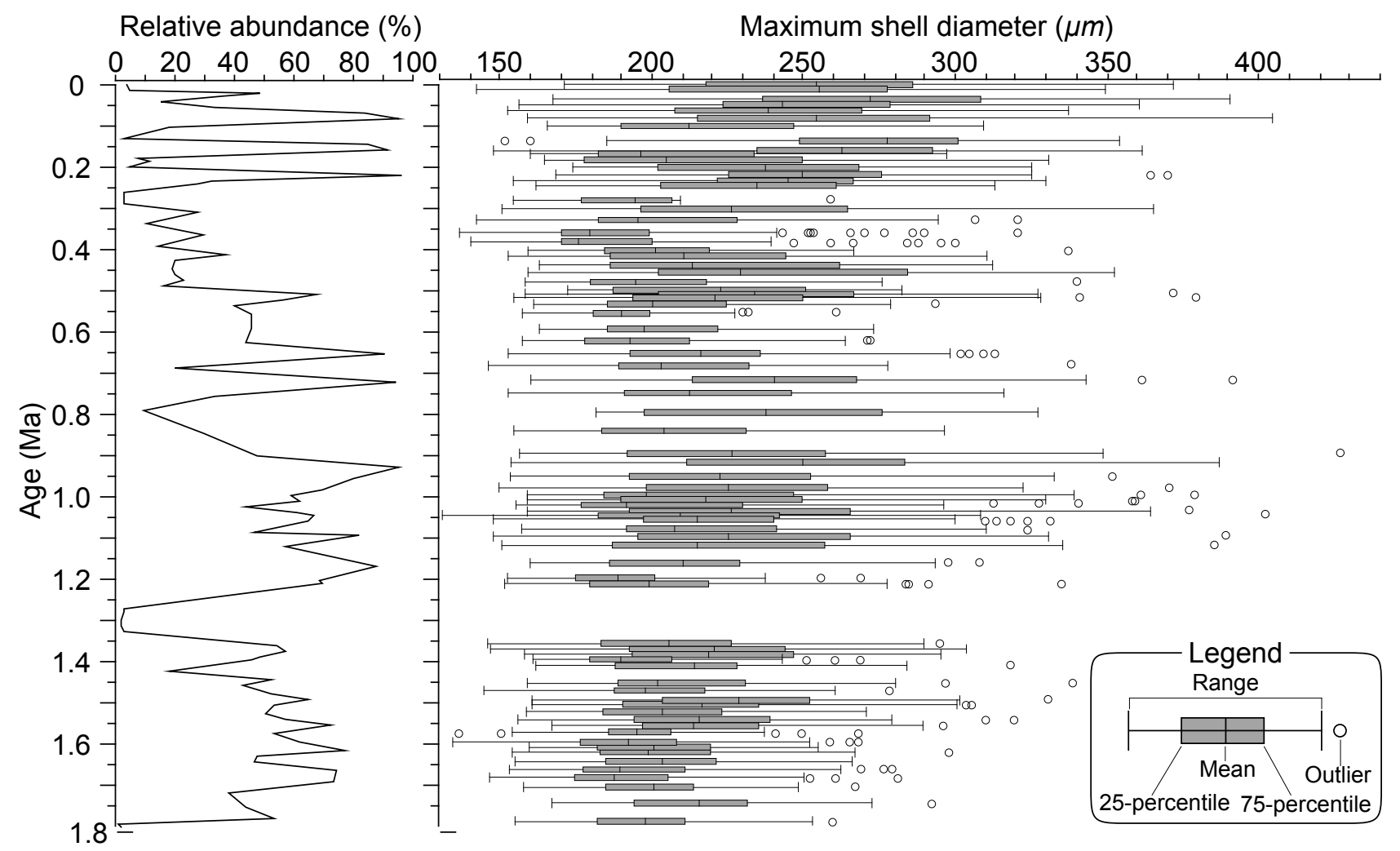

Fig. (2). Relative abundance of Neogloboquadrina pachyderma ( $\sin$ (left panel), and maximum shell diameter of the species (right panel) at Site U1304. Horizons which yielded less than 10 specimens (Table 1) are not shown.

correlate our dataset with these studies, comparing the maximum diameter of $N$. pachyderma $(\sin )$. The study area is very appropriate for obtaining a long-term record of morphological change in $N$. pachyderma ( $\sin )$, because environmental conditions at the southernmost part of the subarctic water mass potentially provide robust occurrences of the species during the Quaternary. In fact, N. pachyderma ( $\sin )$ has continuously occurred in moderate to high abundance throughout the Quaternary section at Site U1304 (Table 1).

Based on the temporal changes of MSS and occurrences of large sized specimens in our study, N. pachyderma $(\sin )$ clearly shows a remarkable variation in shell size after 1.1 Ma (Fig. 2). Especially, larger specimens (>350 $\mu \mathrm{m})$ occur in the interval following 1.1 Ma. The temporal size changes are consistent with the previously obtained data from the Norwegian - Greenland Sea at 1.1 - 1.0 Ma [3] and the northeastern Pacific around $1 \mathrm{Ma}$ [4]. Thus, the shell size change around 1.1 Ma is a bio-event on an inter-ocean basin scale. The correlation between Site U1304 and the other sites $[3,4]$ previously studied in terms of MSS changes clearly shows that MSS at all sites increased throughout the late Quaternary (Fig. 3). Evidence presented by Huber et al. [3] indicates that the largest shell size occurred after $0.4 \mathrm{Ma}$ in the Norwegian - Greenland Sea, confirmed by our data (Fig. 2). The MSS change at Site U1304 is further characterized by a few episodic decreases and increases between $0.6-0.35$ $\mathrm{Ma}$, a similar trend to that observed from Site 1014 in the North Pacific [4]. The minimum value of MSS was found in this interval at Sites U1304 and ODP Site 1014. In this interval, the shell size recessed its trend of increasing. These falloff events also occurred at Sites 907 and 987, in the western Norwegian - Greenland Sea, and Site 909, in the Fram Strait, especially onset of that event is ca. 0.6 Ma. On the other hand, these events were not clear in the eastern Norwegian - Greenland Sea (Sites 985, 643 and 644). In those three sites, the shell size seems to increase rather than decrease between $0.6-0.35 \mathrm{Ma}$ although there are some episodic decrease.

Size changes of planktic foraminifers are believed to be caused by environmental change. Planktic foraminifers typically reach their maximum size within the most favorable environmental conditions, and decrease in size away from such areas $[10,11]$. The period around ca. $0.4 \mathrm{Ma}$ is recognized as "the mid-Brunhes event (MBE)", characterized by more humid interglacial climates with long-lasting warmth $[12,13]$ and also by an unusual global increase in pelagic carbonate production and dissolution [14]. Some unusual sedimentary facies such as laminated diatomaceous oozes as well as hiatuses, were found at around $0.54-0.53 \mathrm{Ma}$ in southern Atlantic pelagic sediments, and these events were considered to be one of the terminal events of the MidPleistocene climatic Transition (MPT; [15]). Furthermore, Wright and Flower [16] suggested that surface water conditions had changed in the subarctic North Atlantic from about $0.66-0.61 \mathrm{Ma}$, coinciding with the establishment of "the 100-kyr world". The intervals of $N$. pachyderma (sin) shell size change correspond to the timing between the end of the MPT and the MBE. We thus suggest that the predominance 
Table 1. Relative Abundance and Maximum Shell Diameter of Neogloboquadrina pachyderma (sin) and, Number of Specimens at Site U1304

\begin{tabular}{|c|c|c|c|c|c|c|c|c|c|}
\hline Age (Ma) & Depth (mcd) & Relative Abundance (\%) & Mean & $\mathbf{n}$ & Age (Ma) & Depth (mcd) & Relative Abundance (\%) & Mean & $\mathbf{n}$ \\
\hline 0.00 & 0.17 & 3.4 & 216.4 & 7 & 0.99 & 163.79 & 69.2 & 229.2 & 172 \\
\hline 0.01 & 2.17 & 5.0 & 252.0 & 9 & 1.00 & 165.80 & 58.8 & 218.5 & 131 \\
\hline 0.02 & 3.87 & 48.8 & 255.6 & 101 & 1.01 & 167.97 & 62.1 & 226.6 & 126 \\
\hline 0.03 & 4.17 & 36.3 & 247.1 & 82 & 1.02 & 169.69 & 44.2 & 204.7 & 90 \\
\hline 0.04 & 6.37 & 15.3 & 270.9 & 42 & 1.04 & 171.69 & 60.6 & 233.9 & 129 \\
\hline 0.05 & 8.37 & 33.5 & 248.0 & 81 & 1.05 & 173.34 & 66.7 & 214.9 & 145 \\
\hline 0.07 & 10.69 & 84.3 & 236.6 & 189 & 1.06 & 175.37 & 65.1 & 220.1 & 132 \\
\hline 0.08 & 12.69 & 95.0 & 255.1 & 241 & 1.09 & 178.98 & 47.2 & 219.3 & 97 \\
\hline 0.11 & 16.69 & 18.5 & 220.1 & 38 & 1.09 & 179.40 & 81.8 & 229.7 & 190 \\
\hline 0.13 & 21.19 & 2.8 & 244.1 & 6 & 1.12 & 182.38 & 56.8 & 225.0 & 115 \\
\hline 0.15 & 23.24 & 85.0 & 273.7 & 182 & 1.17 & 186.36 & 88.0 & 211.1 & 183 \\
\hline 0.16 & 25.24 & 91.3 & 260.3 & 258 & 1.20 & 188.95 & 68.8 & 190.9 & 142 \\
\hline 0.18 & 28.86 & 7.5 & 212.0 & 15 & 1.21 & 190.08 & 69.6 & 203.9 & 145 \\
\hline 0.19 & 30.86 & 11.4 & 223.5 & 21 & 1.27 & 196.58 & 2.5 & 191.6 & 7 \\
\hline 0.20 & 33.86 & 5.1 & 240.8 & 13 & 1.28 & 198.58 & 2.9 & 179.8 & 6 \\
\hline 0.22 & 38.16 & 96.2 & 250.6 & 225 & 1.30 & 202.54 & 2.0 & 233.2 & 3 \\
\hline 0.23 & 40.37 & 32.4 & 242.0 & 67 & 1.31 & 204.54 & 2.2 & 230.8 & 3 \\
\hline 0.24 & 42.37 & 28.0 & 232.2 & 111 & 1.33 & 207.12 & 2.5 & 219.8 & 6 \\
\hline 0.26 & 46.30 & 3.0 & 221.0 & 6 & 1.36 & 213.44 & 54.0 & 207.2 & 126 \\
\hline 0.29 & 50.43 & 3.3 & 195.3 & 10 & 1.37 & 215.44 & 57.0 & 221.2 & 124 \\
\hline 0.31 & 54.26 & 28.0 & 231.9 & 231 & 1.39 & 217.56 & 48.7 & 219.9 & 107 \\
\hline 0.34 & 58.76 & 10.4 & 207.4 & 104 & 1.40 & 219.56 & 45.7 & 195.6 & 100 \\
\hline 0.36 & 62.87 & 29.5 & 187.0 & 152 & 1.42 & 223.56 & 18.6 & 213.8 & 38 \\
\hline 0.39 & 66.95 & 14.4 & 188.7 & 113 & 1.46 & 230.15 & 43.3 & 210.4 & 95 \\
\hline 0.41 & 70.93 & 37.6 & 202.8 & 79 & 1.48 & 232.15 & 52.7 & 201.6 & 117 \\
\hline 0.43 & 75.29 & 20.1 & 216.2 & 43 & 1.49 & 234.15 & 64.8 & 227.5 & 188 \\
\hline 0.45 & 79.79 & 19.1 & 224.2 & 46 & 1.51 & 236.01 & 53.1 & 215.7 & 112 \\
\hline 0.46 & 83.77 & 19.9 & 244.0 & 40 & 1.52 & 238.00 & 50.4 & 205.1 & 115 \\
\hline 0.48 & 88.48 & 22.5 & 203.7 & 53 & 1.54 & 240.15 & 57.1 & 217.1 & 146 \\
\hline 0.49 & 92.46 & 16.6 & 218.8 & 35 & 1.56 & 242.13 & 72.1 & 218.0 & 187 \\
\hline 0.51 & 96.67 & 68.2 & 236.4 & 148 & 1.57 & 244.13 & 53.1 & 195.5 & 109 \\
\hline 0.52 & 101.18 & 55.8 & 225.0 & 129 & 1.59 & 246.51 & 62.2 & 193.2 & 210 \\
\hline 0.54 & 105.37 & 39.9 & 205.0 & 87 & 1.61 & 249.21 & 77.5 & 201.1 & 180 \\
\hline 0.56 & 110.36 & 46.1 & 190.8 & 111 & 1.63 & 251.07 & 47.8 & 202.9 & 90 \\
\hline 0.59 & 114.59 & 45.9 & 204.4 & 92 & 1.64 & 253.07 & 46.3 & 203.2 & 88 \\
\hline 0.63 & 119.08 & 43.9 & 197.9 & 84 & 1.66 & 255.08 & 74.0 & 194.8 & 181 \\
\hline 0.66 & 123.07 & 90.1 & 218.7 & 186 & 1.69 & 257.08 & 73.8 & 191.4 & 142 \\
\hline 0.69 & 127.42 & 20.4 & 208.3 & 41 & 1.72 & 259.43 & 38.0 & 201.6 & 72 \\
\hline 0.72 & 131.73 & 94.1 & 241.7 & 248 & 1.75 & 261.51 & 44.2 & 215.0 & 96 \\
\hline 0.75 & 135.79 & 33.7 & 219.1 & 92 & 1.78 & 263.51 & 53.6 & 191.3 & 111 \\
\hline 0.79 & 140.29 & 9.2 & 236.2 & 24 & 1.80 & 265.51 & 1.4 & 245.0 & 3 \\
\hline 0.84 & 144.43 & 29.3 & 207.2 & 71 & 1.81 & 267.51 & 4.0 & 201.2 & 9 \\
\hline 0.90 & 152.45 & 48.0 & 233.6 & 94 & 1.82 & 268.00 & 1.3 & 209.5 & 3 \\
\hline 0.93 & 156.45 & 95.3 & 246.8 & 177 & 1.86 & 273.09 & 0.0 & 207.1 & 4 \\
\hline 0.95 & 159.28 & 79.6 & 229.0 & 162 & & & & & \\
\hline
\end{tabular}




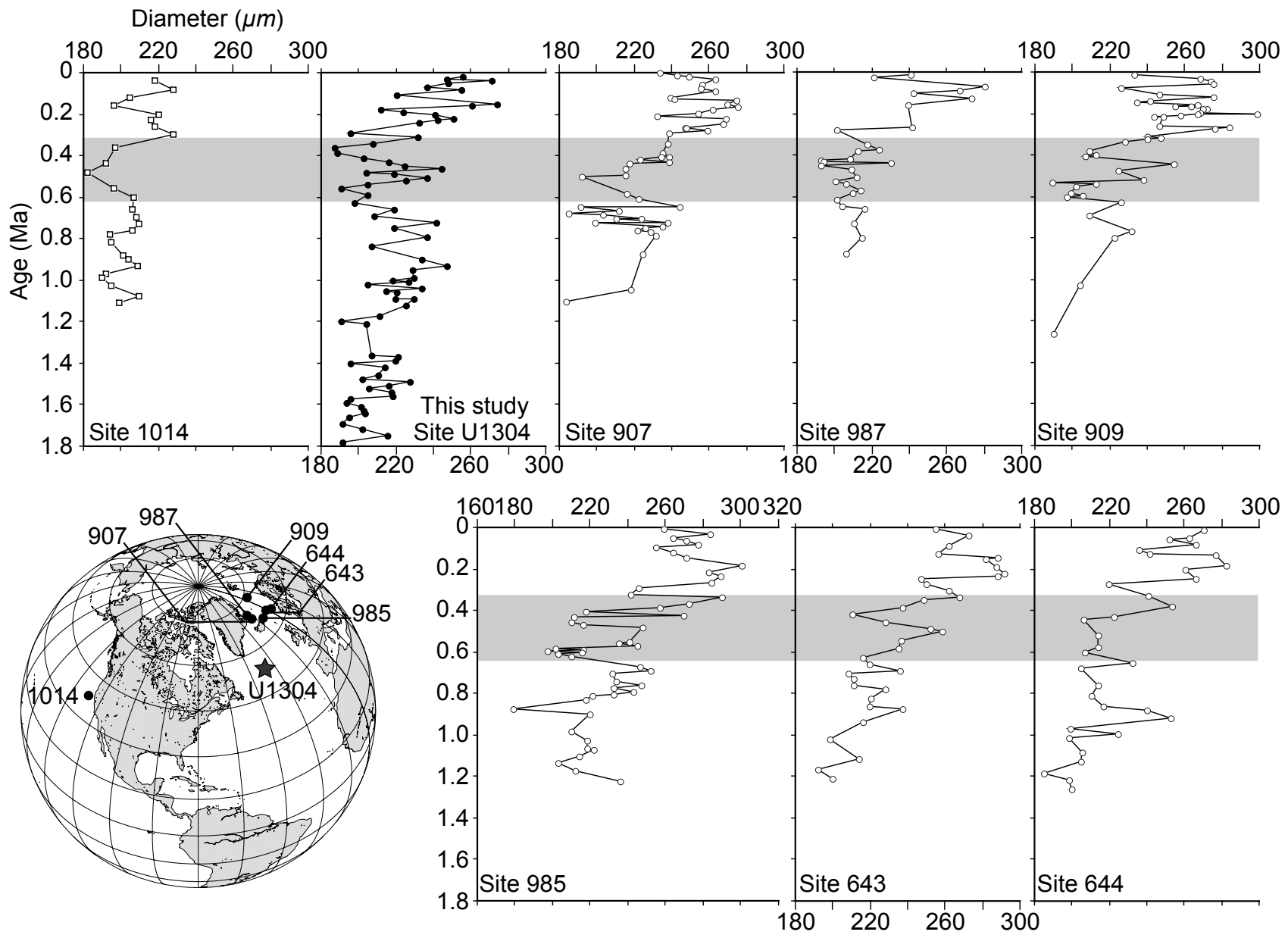

Fig. (3). Correlation of mean shell size between the North Pacific (open square) [4], North Atlantic (solid circle; this study), and the Norwegian - Greenland Sea (open circle) [3]. Map showing locations of ODP and IODP sites presented in this figure. Shaded area shows the duration which shell size decrease.

of humid and long-lasting warmer conditions and/or surface water instability at about $0.6-0.35 \mathrm{Ma}$ was likely to prevent faunal dominance of $N$. pachyderma $(\sin )$, and resulting in the decrease of the shell size. These morphological findings confirm the adaptation of this species to cold water habitats.

Recently, molecular biological evidence has revealed the phylogenetic origin of this species [17, 18, 19]. Darling et al. [20] suggested that populations of $N$. pachyderma $(\sin )$ between the North Atlantic and North Pacific oceans have been genetically isolated from each other with no gene flow since the early Pleistocene. If this is true, the shell size change of $N$. pachyderma $(\sin )$ during ca. $0.6-0.35 \mathrm{Ma}$ can be interpreted as a sensitive reaction of the species to environmental and climate change common at both oceans the North Atlantic and eastern North Pacific.

\section{CONCLUSIONS}

Neogloboquadrina pachyderma ( $\sin )$ has increased in mean test size since the mid-Quaternary $(1.1 \mathrm{Ma})$. This trend in test size at the North Atlantic subarctic convergence zone is consistent with test size changes reported from other regions of the northern Atlantic [3] and the eastern Pacific [4]. Based on a correlation of shell size change of this species in the North Atlantic and North Pacific, shell size decrease event around ca. 0.6 $\mathrm{Ma}$ is supposed to be an inter-ocean scaled bioevent, caused by changes of the global climate.

\section{ACKNOWLEDGEMENTS}

We sincerely appreciate the support of captain, crews and technical staffs of IODP Expedition 303. Thanks also to Saiko Toyoshima for micropaleontological sample preparations. R. Schiebel at University of Southampton and two anonymous reviewers helped to improve the manuscript with constructive comments. Financial support was given to TS (Grand-In -Aid for Scientific Research; No. 19340155).

\section{REFERENCES}

[1] Ericson DB. Coiling direction of Globigerina pachyderma as a climatic index. Science 1959; 130: 219-20.

[2] Bé AHW. An ecological zoogeographic and taxonomic review of recent planktic foraminifera. In: Ramsay ATS, Ed. Oceanic Micropaleontology; 1: London, Academic Press 1977; 1-100.

[3] Huber R, Meggers H, Baumann K-H, Raymo ME, Heinrich R. Shell size variation of the planktonic foraminifer Neogloboquadrina pachyderma sin. in the Norwegian-Greenland Sea during the last 1.3 Myrs: implications for paleoceanographic reconstructions. Palaecogeogr Palaeoclimatol Palaeoecol 2000; 160: 183-212. 
[4] Kucera M, Kennett JP. Causes and consequences of a middle Pleistocene origin of the modern planktonic foraminifer Neogloboquadrina pachyderma sinistral. Geology 2002; 30: 539-42.

[5] Schmidt DN, Thierstein HR, Bollmann J, Schiebel R. Abiotic forcing of plankton evolution in the Cenozoic. Science 2004; 303: 20710 .

[6] Channell JET, Kanamatsu T, Sato T, Stein R, Alvarez Zarikian, CA, Malone, MJ, the Expedition 303/306 Scientists. Proc IODP 303/306 2006 [cited 2008 May 8]; Available from: http://publications.iodp.org/proceedings/303_306/30306toc.htm

[7] Kennett JP, Srinivasan MS. Surface ultrastructural variation in Neogloboquadrina pachyderma (Ehrenberg): phenotype variation and phylogeny in the late Cenozoic. Cushman Foundation Special Publication 1980; vol. 19: 134-62.

[8] Weaver PPE, Clement BM. Magnetobiostratigraphy of planktonic foraminiferal datums. Init Repts DSDP 1987; 94(Pt 2) [cited 2008 May 8]; Available from: http://www.deepseadrilling.org/94/volume/dsdp94pt2 20.pdf

[9] Meggers H, Baumann K-H. Late Pliocene/Pleistocene calcareous plankton and paleoceanography of the North Atlantic. In: Hass HC, Kaminski MA, Eds. Contributions to the micropaleontology and paleoceanography of the northern North Atlantic; Grzybowski Foundation Special Publication 1997; vol. 5: 39-50.

[10] Schmidt DN, Renaud S, Bollmann J, Schiebel R, Thierstein HR. Size distribution of Holocene planktic foraminifer assemblages: biogeography, ecology and adaptation. Marine Micropaleontol 2004; 50: 319-38.

[11] Schmidt DN, Lazarus D, Young JR, Kucera M. Biogeography and evolution of body size in marine plankton. Earth-Sci Rev 2006; 78: 239-266.

[12] Jansen JHF, Kuijpers A, Troelstra SR. A Mid-Brunhes climatic event: long term changes in global atmosphere and ocean circulation. Science 1986; 232: 619-22.
[13] Hodell DA, Charles CD, Ninnemann US. Comparison of interglacial stages in the South Atlantic sector of the southern ocean for the past 450 kyr: implications for Marine Isotope Stage (MIS) 11. Glob Planet Change 2000; 24: 7-26.

[14] Barker S, Archer D, Booth L, Elderfield H, Henderiks J, Rickaby REM. Globally increased pelagic carbonate production during the Mid-Brunhes dissolution interval and the CO2 paradox of MIS 11. Quat Sci Rev 2006; 25: 3278-93.

[15] Schmieder F, von Dobeneck T, Bleil U. The mid-Pleistocene climate transition as documented in the deep South Atlantic Ocean: initiation, interim state and terminal event. Earth Planet Sci Lett 2000; 179: 539-49.

[16] Wright AK, Flower BP. Surface and deep ocean circulation in the subpolar North Atlantic during the mid-Pleistocene revolution. Paleoceanography 2002; 17: 1068, doi:10.1029/2002PA000782.

[17] Darling KF, Wade CM, Stewart IA, Kroon D, Dingle R, Brown AJL. Molecular evidence for genetic mixing of Arctic and Antarctic subpolar populations of planktonic foraminifers. Nature 2000; 405; 43-7.

[18] Darling KF, Kucera M, Pudsey CJ, Wade CM. Molecular evidence links cryptic diversification in polar planktonic protists to Quaternary climate dynamics. Proc Natl Acad Sci USA 2004; 101: 765762.

[19] Darling KF, Kucera M, Kroon D, Wade CM. A resolution for the coiling direction paradox in Neogloboquadrina pachyderma. Paleoceanography 2006; 21: PA2111, doi: 10.1029/2005PA00 1189, 2006.

[20] Darling KF, Kucera M, Wade CM. Global molecular phylogeography reveals persistent Arctic circumpolar isolation in a marine planktonic protist. Proc Natl Acad Sci USA 2007; 104: 5002-7.

[21] Bodén P, Backman J. A laminated sediment sequence from the northern North Atlantic Ocean and its climatic record. Geology 1996; 24: 507-10. 